\title{
Periostin, a signal transduction intermediate in TGF- $\beta$-induced EMT in U-87MG human glioblastoma cells, and its inhibition by anthocyanidins
}

\author{
Amira Ouanouki ${ }^{1}$, Sylvie Lamy ${ }^{1}$ and Borhane Annabi ${ }^{1}$ \\ ${ }^{1}$ Laboratoire d'Oncologie Moléculaire, Centre de Recherche BioMed, Université du Québec à Montréal, C.P. 8888, Succ. \\ Centre-ville, Montréal, Québec, Canada H3C 3P8 \\ Correspondence to: Borhane Annabi, email: annabi.borhane@vqam.ca \\ Keywords: anthocyanidins; EMT; glioblastoma; periostin; TGF- $\beta$ \\ Received: May 07, $2017 \quad$ Accepted: April 04, $2018 \quad$ Published: April 24, 2018 \\ Copyright: Ouanouki et al. This is an open-access article distributed under the terms of the Creative Commons Attribution License 3.0 (CC \\ BY 3.0), which permits unrestricted use, distribution, and reproduction in any medium, provided the original author and source are credited.
}

\section{ABSTRACT}

Periostin is a secreted protein that is highly expressed in glioblastoma cells as compared to normal brain tissue, and is therefore considered as a potential biomarker in therapeutic modalities. Its contribution in the cancer cells invasive phenotype is, however, poorly understood. This work investigates the role of periostin in U-87 MG glioblastoma cell invasion, cell migration and in Transforming Growth Factor $\beta$ (TGF- $\beta$ ) -induced epithelial-mesenchymal transition (EMT). Periostin gene silencing, using small interfering RNA, decreased TGF- $\beta$-induced mesenchymal marker expression of fibronectin and vimentin, partly through reduced Smad2, Akt and Fak phosphorylation as well as U-87 MG cell invasion and migration. The effects of anthocyanidins, the most abundant diet-derived flavonoids, were examined on periostin-mediated downstream signaling pathways. Anthocyanidins were found to decrease periostin expression whether added under pre-, co- or post-treatment conditions along with TGF- $\beta$, and altered the Akt and Fak signaling pathways. These effects were similar to Galunisertib (LY2157299), a small molecule inhibitor of the TGF- $\beta$ receptor I kinase. Taken together, our data demonstrate that periostin acts as a central element in TGF$\beta$-induced EMT, which can be prevented by diet-derived anthocyanidins.

\section{INTRODUCTION}

Periostin, originally named osteoblast-specific factor-2 (Osf2), is a $93.3 \mathrm{kDa}$ matricellular protein known to play roles in osteology and tissue repair in the cardiovascular and respiratory systems [1]. It is also involved in tumor development where it promotes cancer cell survival, invasion, migration and angiogenesis leading to epithelial-mesenchymal transition (EMT) and metastasis [2]. Periostin is found in normal adult tissues such as aorta, stomach, breast, lung, thyroid, colon, ovary and prostate, whereas it is overexpressed in various cancer types including neuroblastoma, head and neck, colon, thyroid, ovarian and breast cancers [3]. Studies suggest that the molecular processes involved in metastasis, invasion and cell survival may be regulated through periostin functions [4]. It is believed that periostin plays a dual role in this respect as it can also act as a suppressor of tumor progression in several types of cancer [2].
EMT plays an important role in physiological processes such as in embryonic development, but also in pathologic processes such as tumor progression [5]. EMT promotes dissemination of primary epithelial cancer cells to distant sites thus regulating the metastasis and malignant behavior of the primary tumor [6]. EMT is triggered by several growth factors, including TGF- $\beta$, and is characterized by the induction of mesenchymal markers such as periostin, fibronectin, $\beta$-catenin and vimentin and by the loss of epithelial markers such as occludin, claudin and E-cadherin [7]. Several studies have suggested that periostin expression and its secretion, driven by TGF- $\beta$, play a role as an EMT inducer [8].

Secreted periostin acts, in part, through integrin receptors $\alpha v \beta 3$ and $\alpha v \beta 5$ to activate the Akt survival and Fak invasive pathways leading to EMT and metastasis $[9,10]$. On the other hand, little is known about the role for periostin in glioma, aside from its expression being correlated with glioma tumor grade and survival [9]. The 
mechanisms by which periostin contributes to glioma malignancy therefore requires more investigation.

Glioblastoma multiforme (GBM) is the most common malignant tumor of the primary central nervous system (CNS) [11]. GBM is highly invasive which makes it resistant to radiotherapy and chemotherapy, and so the median survival time of GBM patients is less than 15 months [12]. Current GBM treatment includes maximal resection followed by radiotherapy along with temozolomide as chemotherapy. Despite this therapeutic regimen, patients suffer recurrence and only 3-5\% survive 5 years after diagnosis [13]. Given that several EMT-targeting molecules have advanced into clinical trials, with chemical structures often inspired from those of natural diet-derived compounds, assessment of their chemopreventive properties may lead to novel strategy in metastasis suppression [14].

In the present study, we tested anthocyanidins, a class of flavonoids with a wide range of reported healthpromoting pharmacological effects on obesity control, cancer and cardiovascular disease [15]. Specifically, we investigated the role of periostin in glioblastoma cell invasion, cell migration and on TGF- $\beta$-induced EMT. We also assessed the effects of anthocyanidins on signaling pathways and compared them to those of Galunisertib, a phase II experimental drug, known to also target TGF- $\beta$ receptor-mediated signaling in GBM $[16,17]$.

\section{RESULTS}

\section{TGF- $\beta$ induces periostin expression in U-87 MG Cells}

We measured the effects of TGF- $\beta$ on periostin expression in U-87 MG cells and found that it induced the expression of periostin in a time-dependant manner (Figure 1A) to reach a plateau at $10 \mathrm{ng} / \mathrm{mL}$ TGF- $\beta$ (Figure 1B). TGF- $\beta$-induced periostin expression was also confirmed by immunofluorescence (Figure 1C). Periostin gene expression levels were also found up-regulated upon TGF- $\beta$ treatment (Figure 1D). Taken together, these results demonstrate that periostin is efficiently regulated upon TGF- $\beta$-mediated signaling in U-87 MG cells.

\section{Periostin repression alters TGF- $\beta$-induced EMT biomarkers expression}

Next, the role of periostin in TGF- $\beta$-induced EMT was evaluated. Periostin was silenced using siRNA, TGF- $\beta$ was added to cells for $48 \mathrm{~h}$, and the protein expression of several EMT markers evaluated by immunoblotting. Periostin repression was found to reduce TGF- $\beta$-induced expression of both fibronectin and vimentin by 70 and $80 \%$, respectively. $\beta$-Catenin, twist and Snail expression were unaffected (Figure 2A). Periostin gene silencing was confirmed by quantitative PCR in the presence of TGF- $\beta$
(Figure 2B). These results position periostin as a new potential signal transduction intermediate within the TGF$\beta$-induced EMT process.

\section{Pre-, co- and post-TGF- $\beta$ treatments with anthocyanidins affect periostin expression}

The possibility that anthocyanidins could affect TGF- $\beta$-induced periostin expression was next examined. As described in the Methods section, U-87 MG cells were incubated with serum-free medium, then pre-, co- or posttreatment was performed in the presence or absence of $50 \mu \mathrm{M}$ anthocyanidins (Cy, cyanidin; Dp, delphinidin; $\mathrm{Pg}$, pelargonidin; Pt, petunidin; Mv, malvidin). After $48 \mathrm{~h}$ of stimulation with TGF- $\beta$, periostin expression levels were evaluated by immunoblotting. Interestingly, all anthocyanidins tested inhibited periostin expression whether used under pre-, co- or post-treatment conditions (Figure 3A-3C), except for co-treatment with $\mathrm{Mv}$ and TGF- $\beta$ (Figure 3B). Dp was found the most potent inhibitor of periostin expression.

\section{Anthocyanidin effects on the expression of TGF- $\beta$-induced periostin}

We next treated U-87 MG cells with various concentrations of anthocyanidins, and determined the half-maximal inhibitory concentration $\left(\mathrm{IC}_{50}\right)$ values on the expression of TGF- $\beta$-induced periostin. All five anthocyanidins down-regulated TGF- $\beta$-induced periostin expression in pre- (Figure 4A), co- (Figure 4B) and posttreatment (Figure 4C) conditions, except for $\mathrm{Mv}$ in the co-treatment condition where we observed a slight nonstatistical difference downward trend (Figure 4B). Dp was the most potent inhibitor of TGF- $\beta$ induced periostin expression with $\mathrm{IC}_{50}$ values of 14,16 and $12 \mu \mathrm{M}$ for pre-, co- and post-treatment conditions, respectively. $\mathrm{Cy}$ and $\mathrm{Mv}$ were less efficient with $\mathrm{IC}_{50}$ values ranging from 35-44 $\mu \mathrm{M}$ for pre- and post-treatment conditions. $\mathrm{Pg}$ and $\mathrm{Pt}$ were able to down-regulate TGF- $\beta$-induced periostin expression with lower $\mathrm{IC}_{50}$ values for pre- (16 and $12 \mu \mathrm{M}$, respectively) and co-treatments (11 and 22 $\mu \mathrm{M}$, respectively) in comparison to post-treatment (33 and $45 \mu \mathrm{M}$, respectively). Overall, each anthocyanidin was efficient in down-regulating TGF- $\beta$-induced periostin expression whether under pre-, co- or post-treatment conditions.

\section{Periostin regulates TGF- $\beta$-induced U-87 MG cell invasion, cell migration and the Smad2, Akt and Fak signaling pathways}

Since processes of cell invasion $[5,18]$ and cell migration [19] are crucial during EMT, we tested whether periostin is involved in TGF- $\beta$-induced U-87 MG invasion and migration. We previously established the 
concentration of TGF- $\beta$ to be used in the cell migration assay with the xCELLigence Real-Time Cell Analysis system [20]. Here, we first determined the appropriate concentration of TGF- $\beta$ to be used for the invasion assay. Prior to the U-87 MG cell invasion or migration assay, TGF- $\beta$ was added to cells for $48 \mathrm{~h}$ and found to trigger invasion in a dose-dependent manner, reaching a plateau between 10-25 ng/mL (Figure 5A). In order to keep the same treatment conditions, TGF- $\beta$ was used at $10 \mathrm{ng} /$ $\mathrm{mL}$ to study periostin's effect on cell invasion. When periostin was silenced, the TGF- $\beta$-induced cell invasion was decreased by $80 \%$ (Figure $5 \mathrm{~B}$ ). This confirms that periostin is effectively involved in TGF- $\beta$-induced U-87 MG cell invasion. Furthermore, cell migration was decreased in a time-dependent manner when periostin was silenced (Figure $5 \mathrm{C}$ ) and by $\sim 60 \%$ after $10 \mathrm{~h}$ of TGF$\beta$-induced migration (Figure 5D). These results confirm the important role of periostin in cell migration. Next, we found that periostin repression reduced the TGF$\beta$-mediated phosphorylation status of Akt and Fak by $60 \%$ for both (Figure $5 \mathrm{E}$ ), in accordance with previous reports [21-23]. Finally, TGF- $\beta$-induced phosphorylation

A
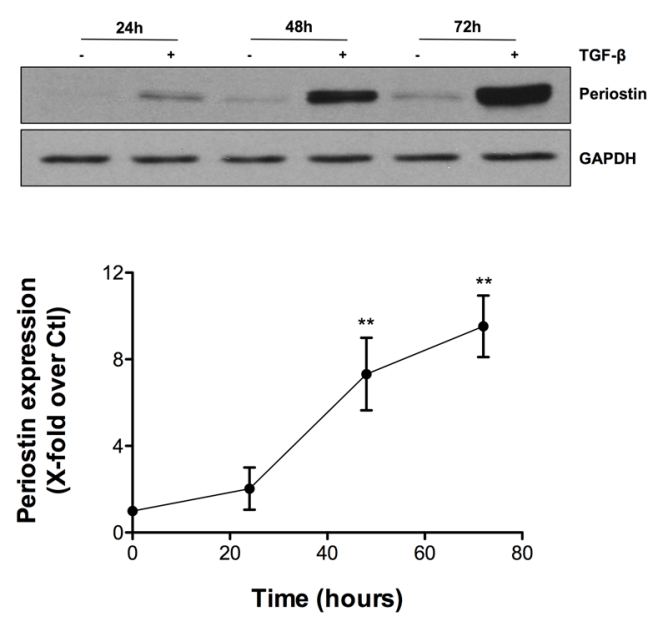

C
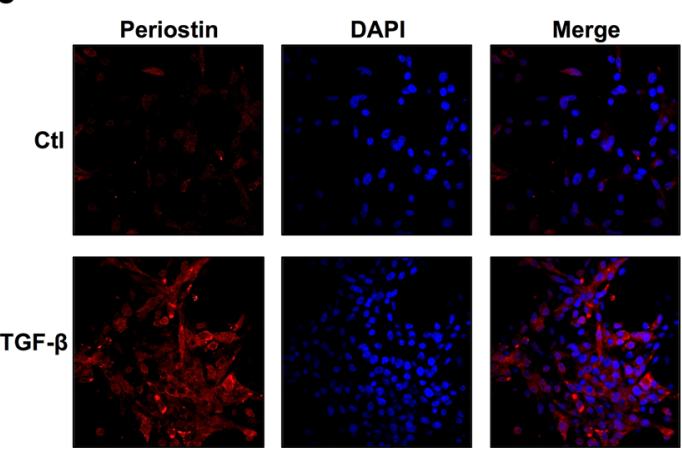

of the Smad 2 signaling pathway was lowered by $40 \%$ (Figure 5E) when periostin was repressed.

\section{Anthocyanidins alter the Akt and Fak signaling pathways}

TGF- $\beta$ is known to trigger cell migration [24, 25] and cell invasion [26] via phosphorylation of Akt and Fak. Consequently, we examined anthocyanidins effects on TGF- $\beta$-induced Akt and Fak phosphorylation. U-87 MG cells were treated with $10 \mathrm{ng} / \mathrm{mL}$ TGF- $\beta$ for $48 \mathrm{~h}$ in pre-, co- and post-treatment condition in the presence of $50 \mu \mathrm{M}$ anthocyanidins (Figure 6), and the phosphorylation status of Akt and Fak were examined using immunoblotting. When compared to similarly stimulated controls, Dp and $\mathrm{Mv}$ decreased the ratio of $\mathrm{pFak} / \mathrm{Fak}$ in pre-treatment condition by 80 and $55 \%$ respectively (Figure 6A). None of the five anthocyanidins tested was able to down-regulate the ratio of $\mathrm{pAkt} / \mathrm{Akt}$ in pre-treatment or $\mathrm{pFak} / \mathrm{Fak}$ in posttreatment conditions. On the other hand, co-treatments with TGF- $\beta$ and Dp, Pt and Mv or post-treatments with $\mathrm{Mv}$, significantly decreased the $\mathrm{pAkt} / \mathrm{Akt}$ ratio by more

B
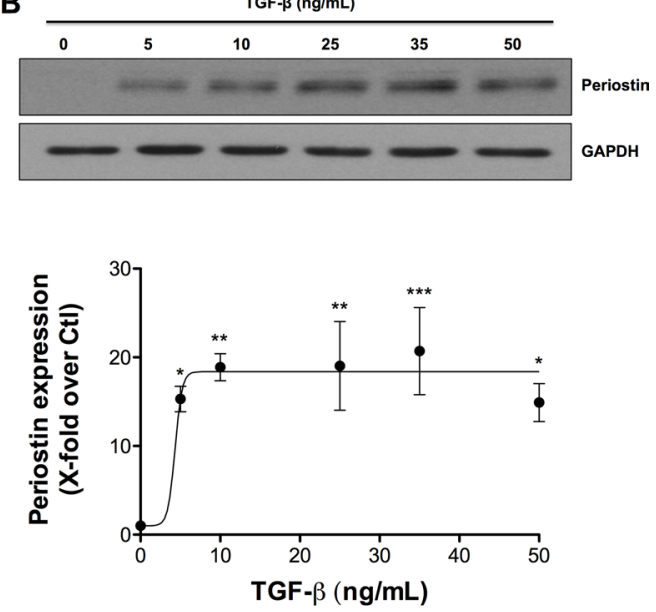

D

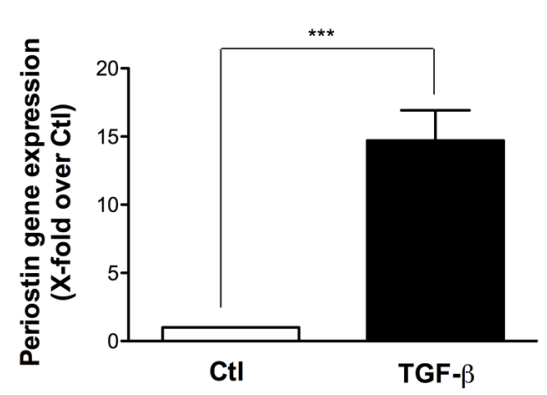

Figure 1: TGF- $\beta$ induces periostin expression in U-87 MG Cells. U-87 MG cells were exposed to TGF- $\beta$. Western blot analysis demonstrated levels of periostin protein expression after (A) treatment with $10 \mathrm{ng} / \mathrm{mL}$ TGF- $\beta$ for 24,48 and $72 \mathrm{~h}$ or $(\mathbf{B})$ treatment with different concentrations of TGF- $\beta$ for $48 \mathrm{~h}$. Densitometric analysis is representative of three or more independent experiments. (C) Photomicrographs show the immunostaining of periostin (red) and nuclei (blue) using fluorescence microscopy. (D) The effect of TGF- $\beta$ on periostin gene expression was evaluated by real-time qPCR. Statistically significant differences were calculated by unpaired Student's $t$ test (D) and one-way ANOVA followed by Bonferroni's test (A, B) $\left({ }^{*} P<0.05,{ }^{* *} P<0.01\right.$, and ${ }^{* * *} P<0.001$ versus control cells). 
than 50\% (Figure 6B and 6C). Interestingly, all five anthocyanidins were able to attenuate phosphorylation of Fak, with inhibition ranging from 50 to $90 \%$ under cotreatment conditions (Figure 6B). These results indicate that anthocyanidins are able to affect TGF- $\beta$-induced phosphorylation of Akt and Fak in U-87 MG cells.

\section{Galunisertib inhibits TGF- $\beta$-induced EMT markers, Smad2, Akt and Fak signaling pathways}

Since TGF- $\beta$ has an important role in tumorigenesis and contributes to tumor proliferation, invasion and metastasis [27], several approaches have been developed to counteract its signaling function. One of the TGF- $\beta$ inhibitors, Galunisertib (LY2157299 monohydrate), has antitumor activity exerted, in part, through specific inhibition of Smad2 phosphorylation [28]. In this study, we compared anthocyanidins to Galunisertib with regard to TGF- $\beta$-induced EMT. Since we have demonstrated inhibitory effects of anthocyanidins on EMT markers
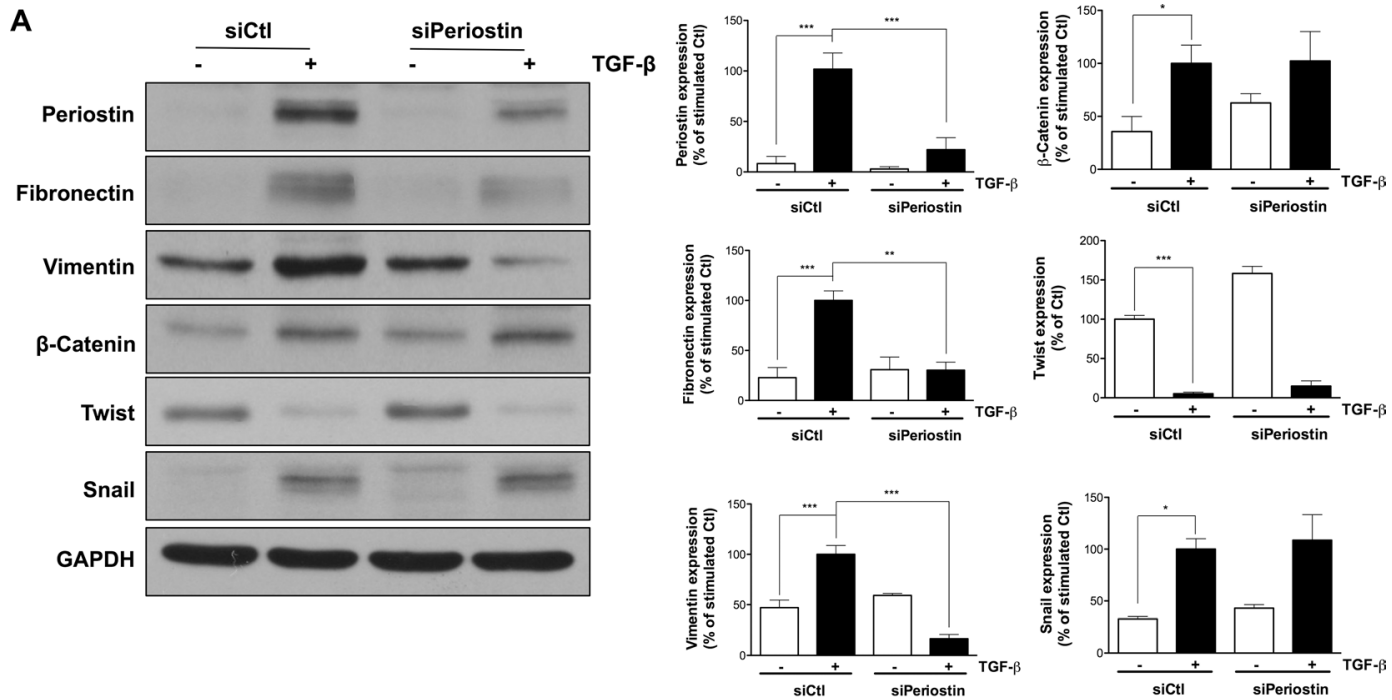

B

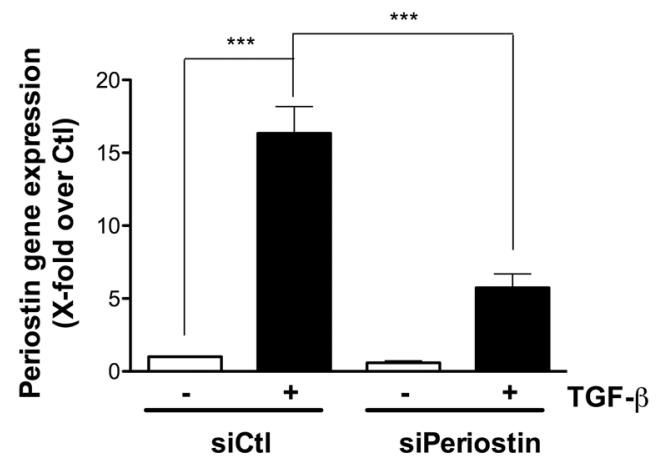

Figure 2: Periostin repression alters TGF- $\boldsymbol{\beta}$-induced EMT biomarkers expression. U-87 MG cells were transfected with $2 \mathrm{nM}$ periostin siRNA for $24 \mathrm{~h}$. (A) Western blot analysis shows protein expression levels of EMT markers. Densitometric analysis is representative of three or more independent experiments. (B) RT-qPCR quantification of periostin gene expression following treatment with $10 \mathrm{ng} / \mathrm{mL}$ TGF- $\beta$ for $48 \mathrm{~h}$. Statistically significant differences were calculated by one-way ANOVA followed by Bonferroni's test ( ${ }^{*} P$ $<0.05,{ }^{* *} P<0.01$, and ${ }^{* * *} P<0.001$ versus control cells). 
marked difference either in the stimulation of the marker expression of periostin, Snail and fibronectin or in the down-regulation of Twist by TGF- $\beta$ in U-87 MG cells as compared to Hs 683, T98G, U-118 MG, U-138 MG and U-251 MG (Supplementary Figure 1). In the present study, we questioned the role of periostin in TGF- $\beta$-mediated EMT. We first found that TGF- $\beta$ effectively induced periostin expression in U87-MG cells, in accordance with studies in PC3 and DU145 prostate cancer cell lines [29]. Here, we also demonstrate for the first time the importance of periostin in the TGF- $\beta$-induced EMT in U-87 MG cells as silencing periostin in U-87 MG cells strongly decreased fibronectin and vimentin levels. Thus, periostin is a key signaling intermediate protein in the regulation of EMTassociated mesenchymal markers in U-87 MG cells.

Glioblastoma (GBM) can be difficult to treat due to its highly invasive and infiltrative phenotype [12]. Few anticancer drugs have been evaluated with GBM in clinical trials and, unfortunately to date, no drug can efficiently treat or prevent GBM recurrence [12]. Preventing EMT, which is activated during cancer invasion and metastasis, has thus become a novel strategy for suppression of tumor progression [14]. Periostin is critical for the EMT process in several types of tumor cells [29-34]. Reports have shown that 293T cells expressing ectopic periostin contributed to EMT and metastatic potential by up-regulating vimentin, epidermal growth factor receptor (EGFR) and matrix metalloproteinase-9 (MMP-9) expression [34]. Up-regulation of periostin has been shown to regulate EMT in adamantinomatous craniopharyngioma cells through the Akt signaling pathway [30].

It is well known that modifying lifestyle and dietary habits may reduce the incidence of several cancers. Epidemiological, in vitro and in vivo studies have shown a decreased incidence of cancer for populations which consume a large variety of fruits, vegetables, nuts, whole grains, fish and olive oil, as is the case for the Mediterranean countries $[35,36]$. Such dietary regimen contains many polyphenolic compounds that are known to confer anticancer properties [37]. Among these phytochemicals, anthocyanins demonstrate a wide range of pharmacological effects such as in obesity control, prevention of cardiovascular diseases, anti-inflammatory effect, anti-tumor activity and protective effects against the skin toxicity induced by radiotherapy $[15,38]$. Our knowledge regarding the effect of diet-derived molecules on periostin is poor. We sought to investigate the anthocyanidins, aglycone forms of anthocyanins, effects on TGF- $\beta$-induced periostin. We demonstrated that, except for co-treatment with $\mathrm{Mv}$, the five anthocyanidins tested significantly decreased TGF- $\beta$-induced periostin expression whether in pre-, co- or post-treatment conditions. It is important to note that anthocyanin plasma concentrations can reach the $\mathrm{mM}$ range $[39,40]$, and that anthocyanins and their metabolites are able to cross the blood-brain barrier and enter the brain [41]. Thus, anthocyanidins could be promising pharmacological
A
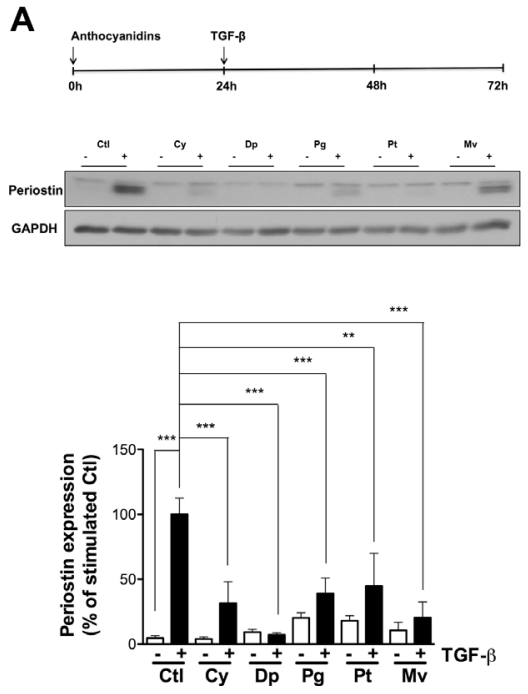

B
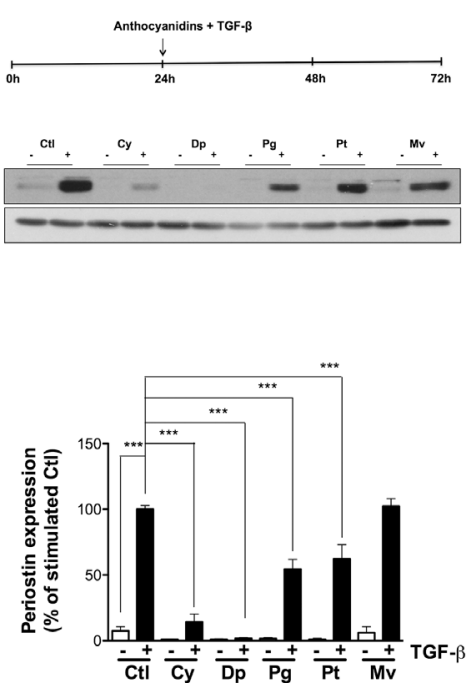

C
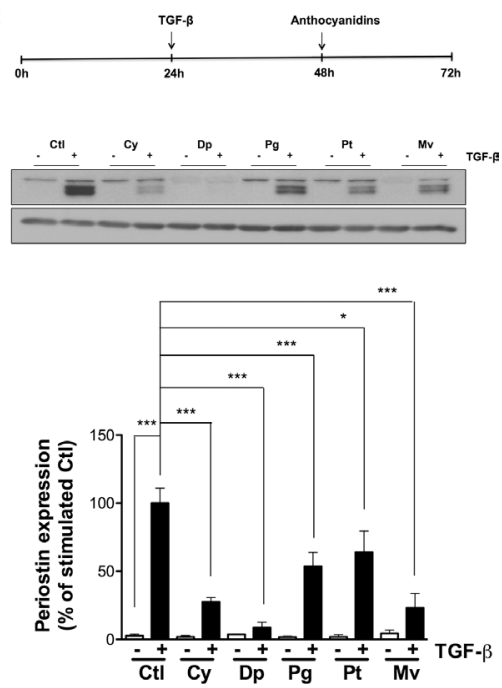

Figure 3: Pre-, co- and post-TGF- $\beta$ treatment with anthocyanidins effects on periostin expression. U-87 MG cells were incubated in serum-free medium containing (or lacking) $50 \mathrm{mM}$ of the indicated anthocyanidin (Cy, cyanidin; Dp, delphinidin; Pg, pelargonidin; Pt, petunidin; Mv, malvidin). Cells were (A) pre-treated with anthocyanidins for $24 \mathrm{~h}$, followed by $10 \mathrm{ng} / \mathrm{mL}$ TGF- $\beta$ for $48 \mathrm{~h}$, or (B) serum-starved for $24 \mathrm{~h}$ and co-treated with anthocyanidins and TGF- $\beta$ for $48 \mathrm{~h}$, or (C) serum-starved for $24 \mathrm{~h}$ followed by the addition of TGF- $\beta$ for $48 \mathrm{~h}$ and post-treated with anthocyanidins for the last $24 \mathrm{~h}$. Cells were lysed and periostin protein expression monitored by immunoblotting. The intensity of the immunoreactive bands was analyzed by densitometry using ImageJ software and expressed as a ratio of periostin to housekeeping protein levels to correct for variations in the amount of proteins loaded. The relative levels of proteins were also normalized to TGF- $\beta$ stimulated cells (value $=100 \%$ ). Statistically significant differences were calculated by one-way ANOVA followed by Bonferroni's test $\left({ }^{*} P<0.05,{ }^{* *} P<0.01\right.$, and ${ }^{* * *} P<0.001$ versus stimulated control). Data are representative of three or more independent experiments. 
A

Pre-treatment
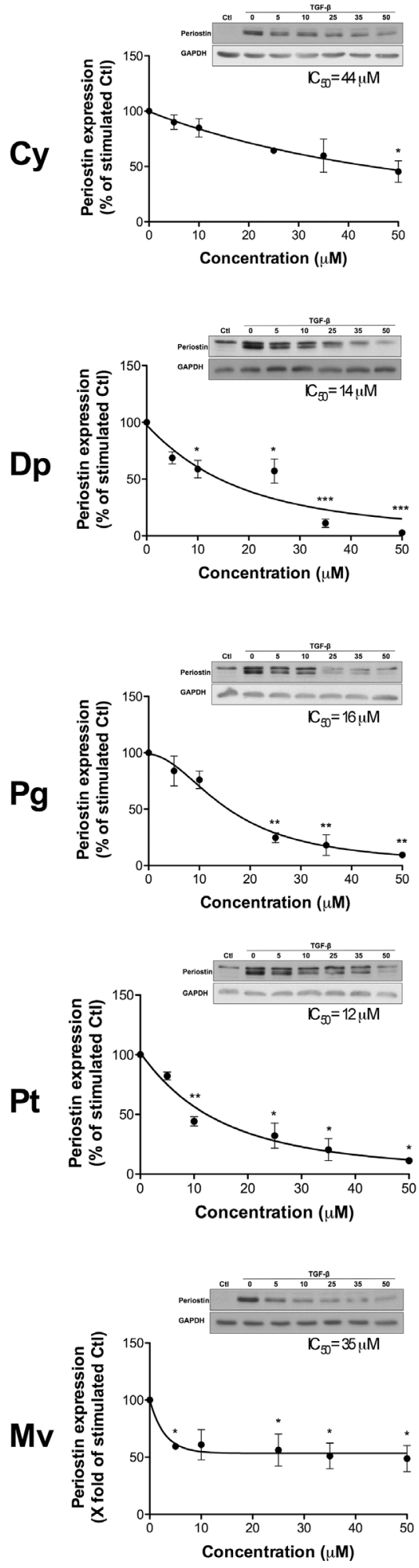
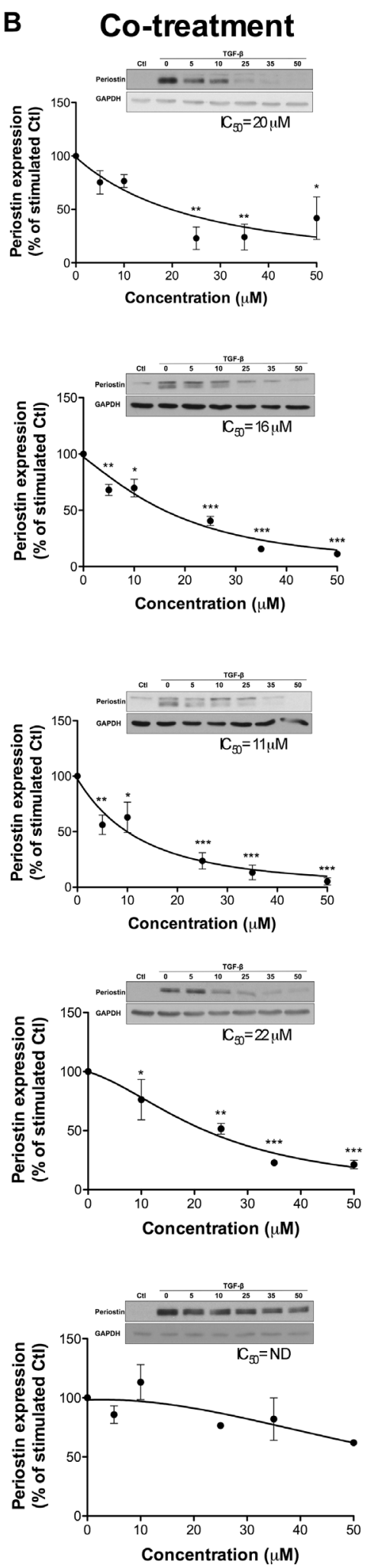

\section{Post-treatment}
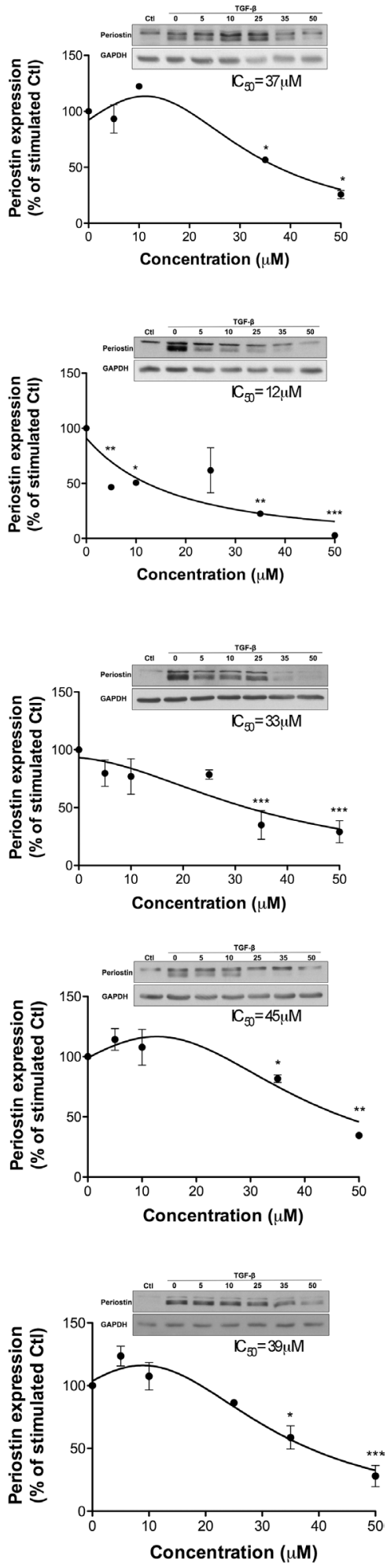

Figure 4: Anthocyanidin effects on the expression of TGF- $\beta$-induced periostin. U-87 MG cells were treated with various concentrations of each anthocyanidin in serum-free medium (A) prior to, (B) along with, or (C) following addition of $10 \mathrm{ng} / \mathrm{mL}$ TGF- $\beta$. Cells were lysed and the periostin protein levels assessed by immunoblotting. The immunoreactive band intensities were analyzed by densitometry using ImageJ software and expressed as a ratio of levels of periostin to those of the housekeeping GAPDH protein to correct for variations in the amount of proteins loaded. The relative levels of proteins were also normalized to the TGF- $\beta$-stimulated condition (value $=100 \%)$. Statistically significant differences were calculated by one-way ANOVA followed by Bonferroni's test $\left({ }^{*} P<0.05,{ }^{* *} P<0.01\right.$, and ${ }^{* * *} P<0.001$ versus stimulated control). Data are representative of three or more independent experiments. 


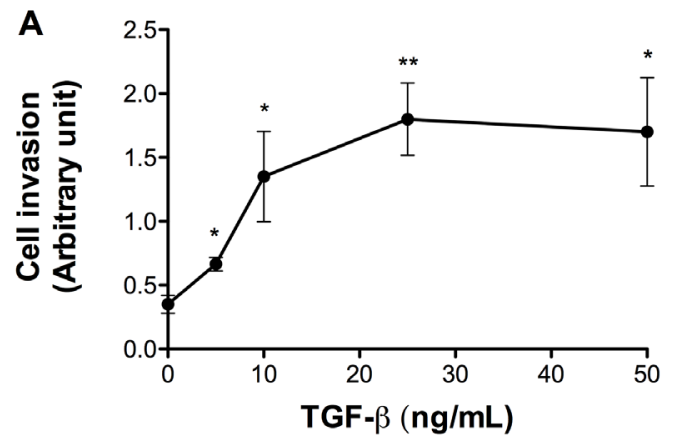

C
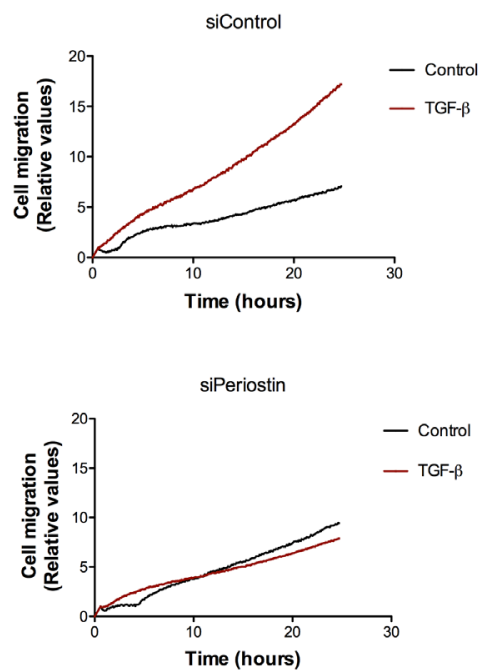

B

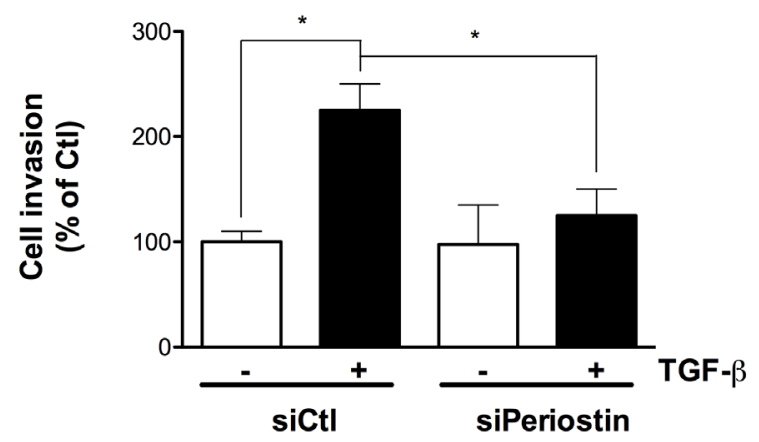

D

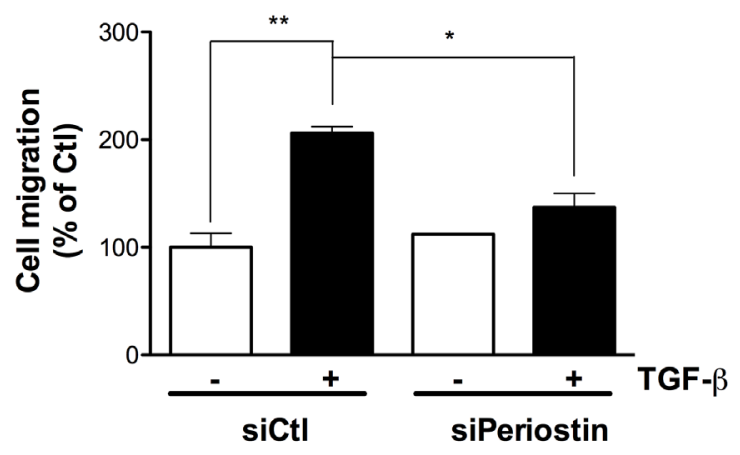

E
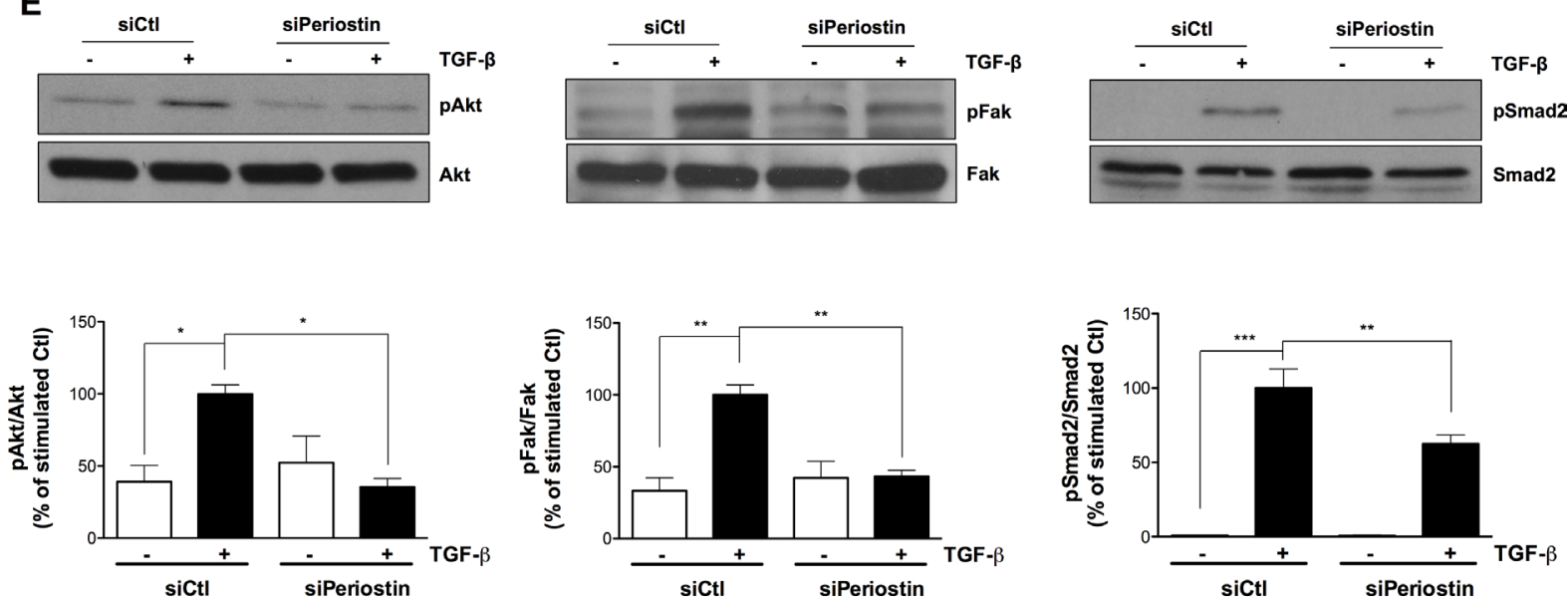

Figure 5: Periostin regulates TGF- $\beta$-induced U-87 MG cell invasion, cell migration and Smad2, Akt and Fak signaling pathways. U-87 MG cells were (A) treated with different concentrations of TGF- $\beta$ for $48 \mathrm{~h}$, or (B-E) transfected with $2 \mathrm{nM}$ periostin siRNA for $24 \mathrm{~h}$ then treated with $10 \mathrm{ng} / \mathrm{mL}$ TGF- $\beta$ for $48 \mathrm{~h}$ before (B) adhesion onto CIM-Plates coated (or not) with Matrigel or (C, D) adhesion onto CIM-Plates coated with $0.15 \%$ gelatin or (E) cell lysis and immunoblotting. Data showing (A, B) TGF- $\beta$-induced invasion of U-87 MG cells at $10 \mathrm{~h},(\mathbf{C})$ Real-Time migration of TGF- $\beta$-induced U-87 MG cells and (D) TGF- $\beta$-induced migration of U-87 MG cells at $10 \mathrm{~h}$. Values are means \pm SEM of three independent experiments performed in quadruplicate. Cell invasion represents the percentage of the ratio of cell index of Matrigel-coated wells to cell index of uncoated wells. Cell migration represents the percentage of the normalized cell index of coated wells. (E) Western blot analysis shows levels of phosphorylated proteins. The immunoreactive band intensities were analyzed by densitometry using ImageJ software and expressed in arbitrary units as a ratio of levels of phosphorylated protein to those of the total protein to correct for variation in the amount of loaded proteins. The relative levels of phosphorylated proteins were also normalized to that of TGF- $\beta$ stimulated controls. Statistically significant differences were calculated by one-way ANOVA followed by Bonferroni's test $\left({ }^{*} P<0.05,{ }^{* *} P<0.01\right.$, and ${ }^{* * *} P<0.001$ versus stimulated control). 
agents for targeting TGF- $\beta$-induced EMT through periostin inhibition.

Cell migration and invasion are key steps in the progression of a tumor leading to a malignant phenotype $[11,42,43]$. It has been reported that periostin expression is correlated with glioma grade and that secreted periostin promoted glioma invasion and adhesion [9]. On the other hand, little is known about the role of periostin in glioma cell migration. Here, we demonstrated the importance of periostin in TGF- $\beta$-induced U-87 MG invasion and migration. The transient knockdown of periostin reduced these two processes. Thus, periostin is a key player in U-87 MG cell invasion and migration in part through regulation of the Smad2, Akt and Fak signaling pathways. Indeed, our current study demonstrates an inhibitory effect of $\mathrm{Cy}, \mathrm{Dp}, \mathrm{Pg}$ and Pt on the TGF- $\beta$ induced phosphorylation of Smad2 with the greatest effect provided by Dp [20]. Moreover, we found that Akt phosphorylation was decreased by $\mathrm{Dp}, \mathrm{Pt}$ and $\mathrm{Mv}$ in cotreatment, and by $\mathrm{Mv}$ only in post-treatment conditions. On the other hand, Fak phosphorylation was reversed by all anthocyanidins in co-treatment and by $\mathrm{Dp}$ and $\mathrm{Mv}$ in pre-treatment. Overall, $\mathrm{Mv}$ was the most potent inhibitor followed by Dp against TGF- $\beta$-induced phosphorylation of the Akt and Fak signaling pathways. Based on our own previous study [20], we further confirm that the inhibition of Akt and Fak phosphorylation was due to anthocyanidin treatments and not cytotoxicity.

The mechanisms by which anthocyanidins target TGF- $\beta$-induced periostin also deserved further consideration. Here, we demonstrated that anthocyanidins alter several TbRI/TbRII and integrin downstream signaling molecules (i.e. Smad2, Akt and Fak). It has been reported that integrins are involved in the activation of TGF- $\beta$ in LN-308 and LNT-229 glioblastoma cell lines [44]. Indeed, exposure to av, $\beta 3$ or $\beta 5$ neutralizing antibodies, RNA interference-mediated integrin gene silencing or the antiangiogenic agent Cilengitide, results in reduced phosphorylation of Smad2 as well as reduced TGF- $\beta$ protein and gene levels [44]. Few studies have reported protective roles for anthocyanins in cardiovascular diseases through integrin inhibition
A
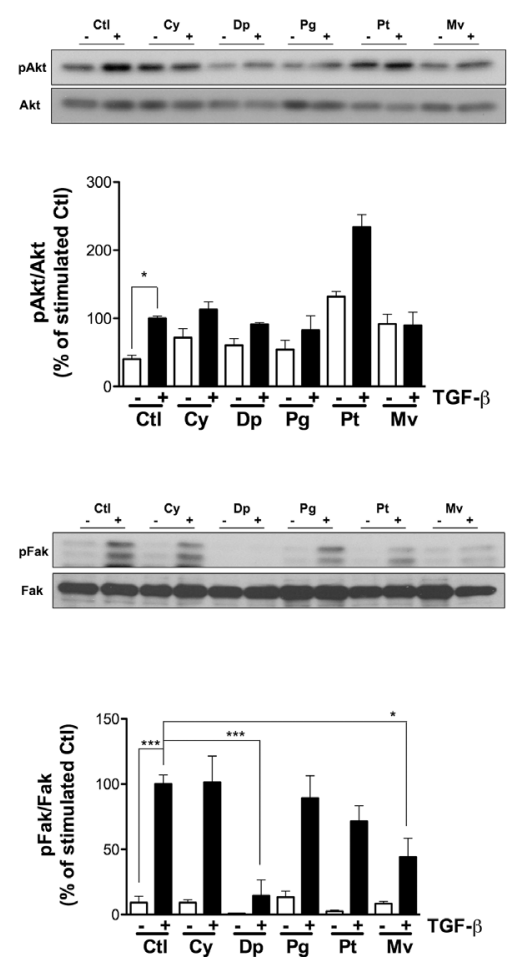

B
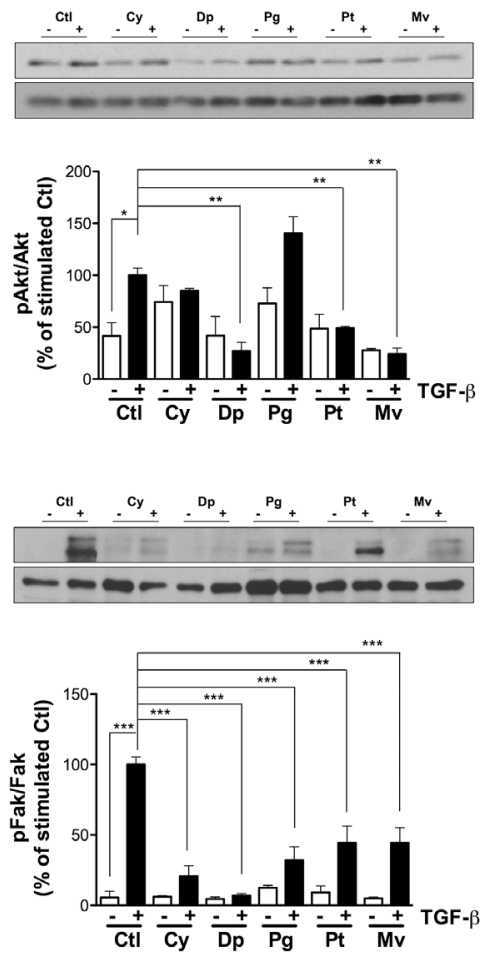

\section{Post-treatment}
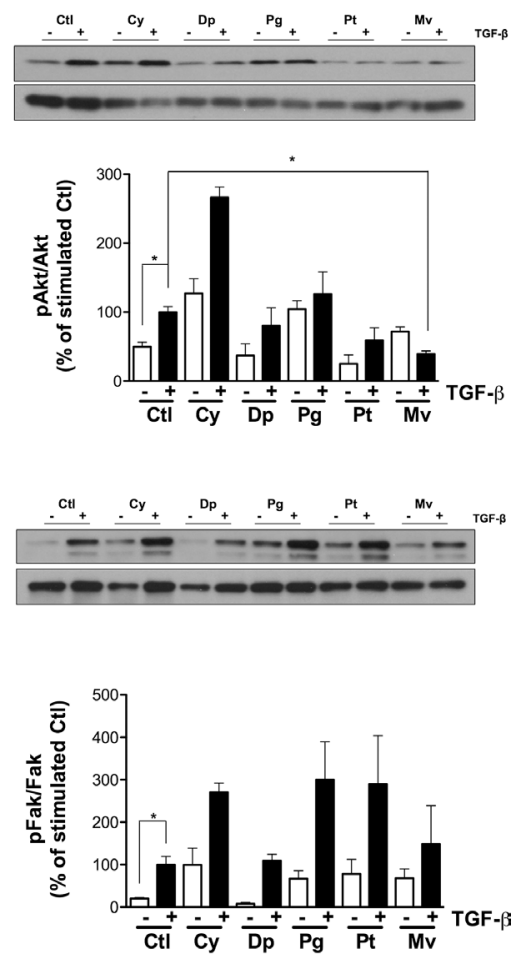

Figure 6: Anthocyanidins alter Akt and Fak signaling pathways. U-87 MG cells were incubated in serum-free medium containing (or lacking) $50 \mu \mathrm{M}$ of the indicated anthocyanidin. Cells were pre-treated with (A) anthocyanidins for $24 \mathrm{~h}$, followed by $10 \mathrm{ng} / \mathrm{mL}$ TGF- $\beta$ for $48 \mathrm{~h}$, or (B) serum starved for $24 \mathrm{~h}$ and co-treated with anthocyanidins and TGF- $\beta$ for $48 \mathrm{~h}$, or (C) serum starved for $24 \mathrm{~h}$ followed by the addition of TGF- $\beta$ for $48 \mathrm{~h}$ and post-treated with anthocyanidins for the last $24 \mathrm{~h}$. After treatments, levels of phosphorylated Akt and Fak proteins, along with their individual total protein levels, were monitored by immunoblotting using specific antibodies. The immunoreactive band intensities were analyzed by densitometry using ImageJ software and expressed in arbitrary units as a ratio of levels of phosphorylated protein to those of the total protein to correct for variation in the amount of protein. The relative levels of phosphorylated protein were also normalized to stimulated controls (value $=100 \%$ ). Statistically significant differences were calculated by one-way ANOVA followed by Bonferroni's test $\left({ }^{*} P<0.05,{ }^{* *} P<0.01\right.$, and ${ }^{* * *} P<0.001$ versus stimulated controls). Data are representative of three or more independent experiments. 
[45-47]. Given periostin capacity to interact with integrin, we can safely speculate that anthocyanidins act through integrin to alter TGF- $\beta$-induced periostin expression in U-87 MG cells.

The inhibitory potential of anthocyanidins is naturally related to their structures, especially to the presence of free hydroxyl groups on the B ring [48]. In our study, Dp showed a better inhibition of TGF- $\beta$-induced periostin expression and Akt/Fak phosphorylation in pre, co-, and post-treatment conditions followed by $\mathrm{Cy}, \mathrm{Pg}$, $\mathrm{Pt}$ and Mv. These results are consistent with our previous findings [20] where Dp also showed better inhibition of TGF- $\beta$-induced mesenchymal markers and TGF- $\beta$ induced Smad 2 phosphorylation in pre-, co- and posttreatment followed by $\mathrm{Cy}, \mathrm{Pg}$ and $\mathrm{Pt}$ in $\mathrm{U}-87 \mathrm{MG}$ cells. However, the Mv effect was not previously assessed. It has been reported that substitution of the hydroxyl groups of the B ring with methoxy groups diminished the antioxidant activity of anthocyanidins [48]. This may explain why Mv, which has $3^{\prime}$ and 5' -dimethoxyl substituents, showed lower inhibition potency than did the 3', 4', 5'-trihydroxylated analogue, Dp.

Therapeutic targeting of the TGF- $\beta$ pathway can slow down tumor progression and metastasis in patients with cancer [49]. Interestingly, several TGF- $\beta$ pathway inhibitors have reached clinical studies such as, Fresolimumab (monoclonal antibody), Lucanix (vaccine), Galunisertib (small molecule inhibitor), Vigil (vaccine), and Trabedersen (antisense oligonucleotide). Among those inhibitors, Galunisertib (LY2157299), a small molecule developed by Eli Lilly and company, is the most advanced with promising results in phase II clinical trials $[17,50]$. However, it has been reported that long-term exposure to Galunisertib caused cardiac toxicities in animal models [28]. In our study, we compared Galunisertib and anthocyanidins by measuring their inhibitory profiles on TGF- $\beta$-induced EMT markers and pathways in a glioblastoma cell line. It is known that Galunisertib is being investigated in patients with glioblastoma, pancreatic cancer and hepatocellular carcinoma [28]. We confirmed that Galunisertib was able to inhibit TGF- $\beta$-induced Smad2 phosphorylation in our glioblastoma cell model, which is supported by previous studies in hepatocellular carcinoma $[51,52]$. Our results further showed that Galunisertib was able to inhibit TGF$\beta$-induced periostin, fibronectin and Snail expression as well as the TGF- $\beta$-induced Akt and Fak phosphorylation, again as shown by data in uterine carcinocarcoma cell lines [53]. Furthermore, it has been shown that Akt phosphorylation decreased in an A172 glioblastoma cell line model treated with Galunisertib [16]. Finally, in HT29 colorectal adenocarcinoma and A549 lung carcinoma cell line models, norepinephrine-induced Snail and vimentin expression were inhibited by Galunisertib [54]. However, Galunisertib was unable to reverse twist inhibition or Erk phosphorylation induced by TGF- $\beta$ (our data). It is interesting to note that the pharmacological action of Galunisertib shares common targets with anthocyanidins, as it is illustrated in Figure 8. Also, we previously demonstrated that anthocyanidins were able to reverse TGF- $\beta$-induced EMT in U-87 MG cells by decreasing mesenchymal markers (fibronectin and Snail) and Smad2 phosphorylation, but were unable to reverse Twist and Erk phosphorylation [20]. As Galunisertib is being investigated in monotherapy modalities and in combination with antitumor regimens [28], it may be legitimate to envision testing consumption of anthocyanidins along with or prior to Galunisertib treatment.

Current cancer management which consists of surgery, chemotherapy and radiotherapy presents limitations such as affordability, availability and undesirable side and adverse effects [55]. Thus, the use of natural diet-derived products for cancer prevention has received remarkable attention in recent years [55]. In this study, we have used three different treatment protocols: pre-, co- and post-treatment of anthocyanidins with TGF- $\beta$. The pre-treatment condition protocol mimics prevention of TGF- $\beta$-induced EMT. On the other hand, co- and post-treatment conditions mimic a TGF- $\beta$-induced EMT as would be associated with advanced cancers. We demonstrated that the five anthocyanidins tested were effective in inhibition or in prevention of TGF- $\beta$-induced EMT in glioblastoma cells.

Overall, our study highlights periostin as a new target of anthocyanidins. This prometastatic protein can be induced by TGF- $\beta$ and downregulated by anthocyanidins in U-87 MG cells whether under pre-, co- or post-treatment conditions. Given the operative SMAD2-mediated signaling pathway, high Snail induction, and optimal Twist expression inhibition, we also believe that it is pertinent to the scientific community to highlight U-87MG cells as the best model to study TGF- $\beta$-induced EMT. Our study finally demonstrates that blocking periostin expression significantly alters TGF- $\beta$-induced EMT and U-87 MG cell invasion and migration. These findings indicate that periostin is a potential therapeutic target for suppressing metastatic progression of glioblastoma cells.

\section{MATERIALS AND METHODS}

\section{Materials}

Anthocyanidin compounds Cy (purity $\geq 96 \%$ ), Dp, Pg, Mv (purity $\geq 97 \%$ ) and Pt (purity $\geq 95 \%$ ) were from Extrasynthese (Lyon, France). Recombinant human TGF- $\beta 1$ was from R\&D Systems (Minneapolis, $\mathrm{MN})$. Electrophoresis reagents were from Bio-Rad (Mississauga, ON). The anti-Twist1 monoclonal antibody was from Santa Cruz Biotechnologies (Dallas, TX). The anti-Periostin antibody was from Abcam (Cambridge, MA). Antibodies against Snail, phospho-Smad2, Smad2, GAPDH (glyceraldehyde-3-phosphate dehydrogenase), 


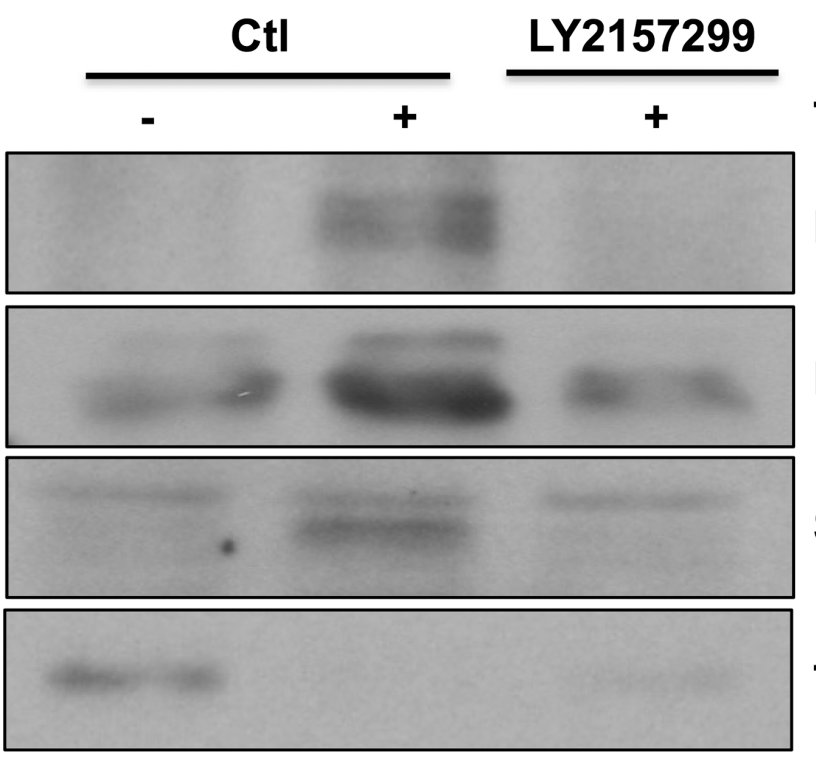

TGF- $\beta$

Periostin

Fibronectin

Snail

Twist

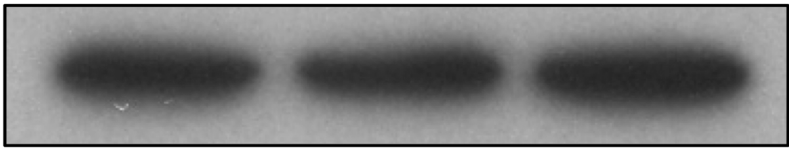

GAPDH

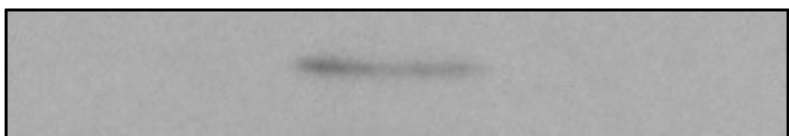

pSmad2

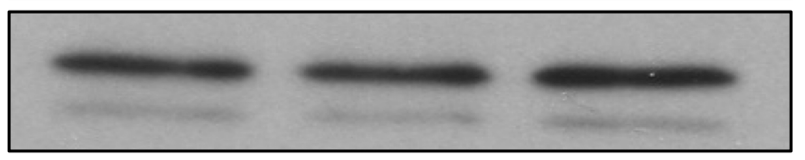

\section{Smad2}

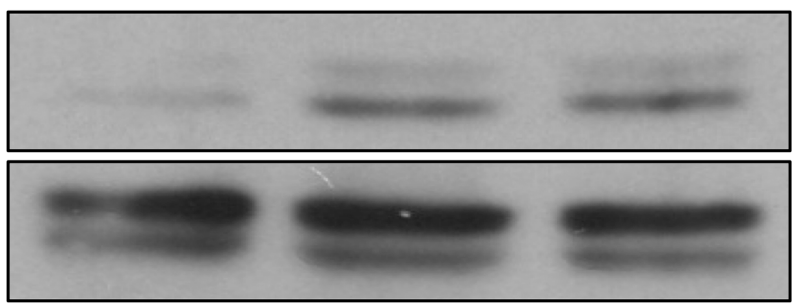

\section{pERK}

\section{ERK}

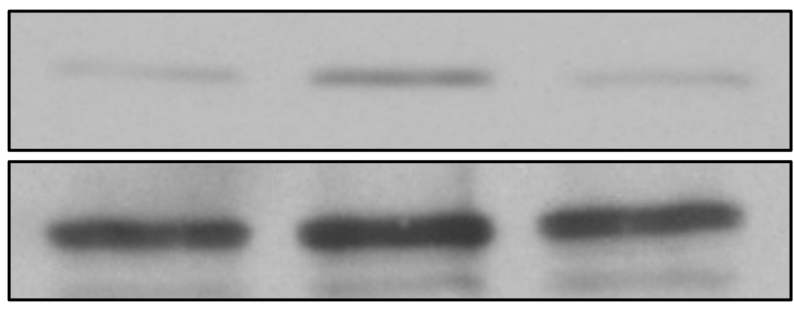

pAkt

Akt

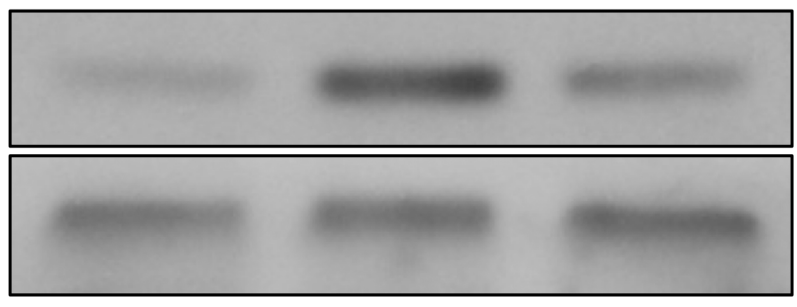

pFak

\section{Fak}

Figure 7: Galunisertib alters TGF- $\beta$-induced EMT markers, Smad2, Akt and Fak signaling pathways. U-87 MG cells were serum-starved for $24 \mathrm{~h}$, then incubated in serum-free medium containing (or lacking) $10 \mu \mathrm{M}$ Galunisertib (LY2157299) and $10 \mathrm{ng} / \mathrm{mL}$ of TGF- $\beta$ for 48 h. Cells were lysed and expression levels of EMT markers periostin, fibronectin, Snail and twist, or the phosphorylation status of Smad2, Erk, Akt and Fak proteins were monitored by immunoblotting. 
vimentin, $\beta$-Catenin, phospho-Fak, Fak, phospho-Akt and Akt were from Cell Signaling Technology (Beverly, MA). The anti-fibronectin antibody was from Sigma Aldrich (Oakville, ON). Anti-mouse and anti-rabbit horseradish peroxidase (HRP)-linked secondary antibodies were from Jackson ImmunoResearch Laboratories (West Grove, PA) and enhanced chemiluminescence (ECL) reagents were from Denville Scientific Inc. (Metuchen, NJ). Micro bicinchoninic acid protein assay reagents were from ThermoFisher Scientific (Rockford, IL).

\section{Cell culture}

The human U-87 MG cell line was purchased from American Type Culture Collection (Manassas, VA). Cells were maintained in Eagle's Minimal Essential Medium (Wisent, 320-036-CL) supplemented with 10\% calf serum (HyClone Laboratories, SH30541.03), $1 \mathrm{mM}$ sodium pyruvate (Sigma-Aldrich, P2256), 2 mM L-glutamine, 100 units/mL penicillin and $100 \mathrm{mg} / \mathrm{mL}$ streptomycin (Wisent, 450-202-EL), and cultured at $37^{\circ} \mathrm{C}$ under a humidified $95 \%-5 \%(\mathrm{v} / \mathrm{v})$ mixture of air and $\mathrm{CO}_{2}$. Cells were treated with vehicle $(0.1 \%$ ethanol $)$ or with anthocyanidins in the absence of serum prior to (pre-treatment), along with (cotreatment) or following (post-treatment) addition of $10 \mathrm{ng} /$ $\mathrm{mL}$ TGF- $\beta$.

\section{Western blot analysis}

In order to study the expression of periostin during TGF- $\beta$ treatment, different concentrations of TGF- $\beta(0-50$ $\mathrm{ng} / \mathrm{mL}$ ) were added to the cells, then a time course was carried out by adding $10 \mathrm{ng} / \mathrm{mL}$ for 24,48 and $72 \mathrm{~h}$. The effect of periostin knockdown on EMT markers, as well as the effect of anthocyanidins on periostin expression and on Akt and Fak phosphorylations, was also evaluated by addition of anthocyanidins $(0-50 \mathrm{mM})$ to the cells as described below. U-87 MG cells were pre-treated with anthocyanidins for $24 \mathrm{~h}$, followed by TGF- $\beta$ for $48 \mathrm{~h}$, or serum starved for $24 \mathrm{~h}$ and co-treated with anthocyanidins and TGF- $\beta$ for $48 \mathrm{~h}$, or serum starved for $24 \mathrm{~h}$ followed by the addition of TGF- $\beta$ for $48 \mathrm{~h}$ and then post-treated with anthocyanidins for the last $24 \mathrm{~h}$. Cells were then washed with ice-cold phosphate-buffered saline (PBS) containing $1 \mathrm{mM}$ each of sodium fluoride $(\mathrm{NaF})$ and sodium orthovanadate $\left(\mathrm{Na}_{3} \mathrm{VO}_{4}\right)$ and incubated in the same medium for $30 \mathrm{~min}$ at $4{ }^{\circ} \mathrm{C}$. Cells were solubilized in lysis buffer [150 mM NaCl, 10 mM Tris-HCl, pH 7.4, 1 mM EDTA, $1 \mathrm{mM}$ ethyleneglycol-O, O'-bis (2-aminoethyl)-N, N, N', N'-tetraacetic acid (EGTA), 0.5\% (vol/vol) Nonidet $\mathrm{P}-40$ and $1 \%(\mathrm{vol} / \mathrm{vol})$ Triton $\mathrm{X}-100]$. The resulting lysates were solubilized in Laemmli sample buffer [125 $\mathrm{mM}$ Tris- $\mathrm{HCl}$ (pH 6.8), 20\% glycerol, 4\% SDS, 10\%

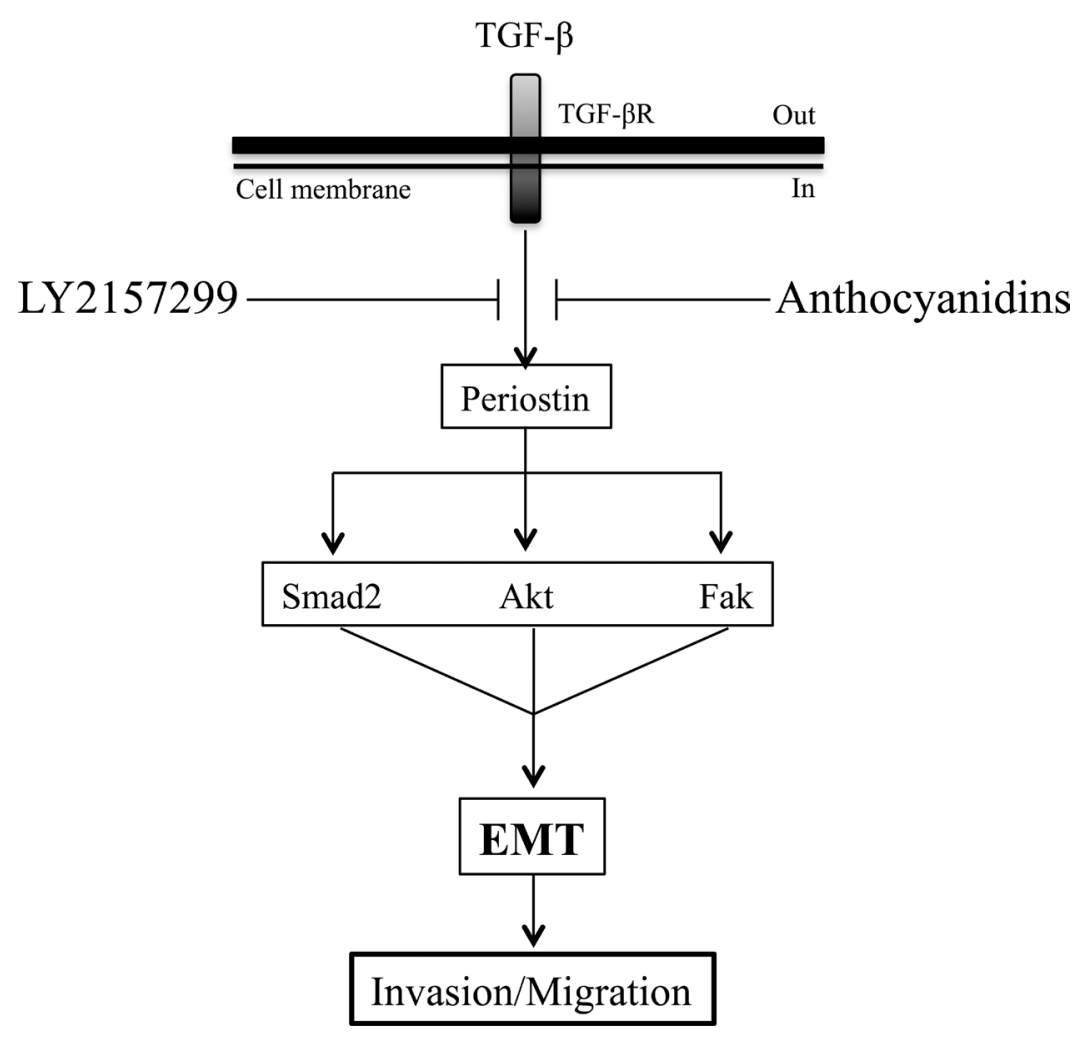

Figure 8: Schematic representation of anthocyanidin and Galunisertib effects on TGF- $\beta$-induced EMT in U-87 MG cells. TGF- $\beta$-induced periostin expression can be suppressed by anthocyanidins and Galunisertib. Smad2, Akt and Fak signaling pathways are activated downstream by periostin upon TGF- $\beta$ treatment. This is reversed by anthocyanidins or Galinosertib treatments, or by periostin silencing. Anthocyanidins block cancer cell invasion, cell migration and EMT, in part, through periostin downregulation. Based on these evidences, periostin may possibly be used as a therapeutic target for EMT in glioblastoma. 
$\beta$-mercaptoethanol, and $0.00125 \%$ bromophenol blue], boiled for $4 \mathrm{~min}$, and separated by sodium dodecyl sulfate-polyacrylamide gel electrophoresis (SDS-PAGE). After electrophoresis, proteins $(20 \mathrm{mg})$ were transferred to polyvinylidene difluoride (PVDF) membranes, which were then blocked for $1 \mathrm{~h}$ at room temperature (RT) with $5 \%$ non-fat dry milk in Tris-buffered saline/Tween 20 (TBS-T; $147 \mathrm{mM} \mathrm{NaCl}, 20 \mathrm{mM}$ Tris-HCl, pH 7.5, and $0.1 \%$ Tween 20). Membranes were further washed three times in TBS-T and incubated with the primary antibody in TBS-T containing 3\% bovine serum albumin (BSA) and $0.03 \%$ sodium azide, followed by a $1 \mathrm{~h}$ incubation with HRP-conjugated anti-mouse or anti-rabbit antibodies in TBS-T containing 5\% non-fat dry milk. Immunoreactive material was visualized using an ECL detection system. The immunoreactive bands were quantified using ImageJ software (NIH).

\section{Immunofluorescence}

U-87 MG cells were seeded on cover slips and treated with vehicle $(0.1 \%$ ethanol $)$ or $10 \mathrm{ng} / \mathrm{mL}$ TGF- $\beta$ for $48 \mathrm{~h}$. Cells were washed twice with ice-cold PBS, fixed in $3.7 \%$ formaldehyde for $20 \mathrm{~min}$ at RT and permeabilized with $0.1 \%$ Triton X-100 for 5 min. Non-specific binding was blocked with $1 \%$ BSA containing $0.03 \%$ sodium azide in PBS overnight at $4^{\circ} \mathrm{C}$. After 3 washes with ice-cold PBS for $15 \mathrm{~min}$, cells were then incubated with the primary anti-periostin antibody $(1: 400)$ for $1 \mathrm{~h}$ at RT, washed twice with cold PBS and incubated with Alexa Fluor-568conjugated anti-rabbit IgG (Invitrogen, CA) at 1:200 for $1 \mathrm{~h}$ at RT. The cell nuclei were visualized using $1 \mathrm{mg} / \mathrm{mL}$ 4', 6-diamidino-2-phenylindole (DAPI) staining for $5 \mathrm{~min}$ at RT. Slides were then dried, mounted with the ProLong Gold antifade reagent (ThermoFisher Scientific, Ottawa, $\mathrm{ON}$ ) and fluorescence examined by confocal microscopy.

\section{siRNA transfections}

Periostin siRNA (Sense:
5'-GCGCC
UCCUUAAAUUAAAUUAAUUTT-3'; $\begin{gathered}\text { Antisense: } \\ \text { 5'-AAUUAAUUUAAGGAGGCGCTG-3') }\end{gathered}$ was from
Qiagen (Valencia, CA). Prior to transient transfections
with both types of siRNAs, U-87 MG cells were
plated into 6-well plates and grown until reaching 70\%
confluence. U-87 MG cells were transfected for $24 \mathrm{~h}$
with 2 nM of either siRNA using Lipofectamine 2000
reagent as described in the manufacturer's instructions
(ThermoFisher Scientific, Ottawa, ON). After transfection,
cells were treated with $10 \mathrm{ng} / \mathrm{mL}$ TGF- $\beta$ for 48 h.

\section{Quantitative PCR analysis}

After cell transfection, total RNA was isolated using TRIzol reagent (Life Technologies, Gaithersburg, MD) and cDNA was synthesized using a high capacity cDNA reverse transcription kit (Applied Biosystems, Foster
City, CA) according to the manufacturer's instructions. Quantitative PCR was performed using SsoFast EvaGreen Supermix (Bio-Rad, Hercules, CA). DNA amplification was carried out using a CFX Connect Real-Time System (Bio-Rad) and product detection was performed by measuring binding of the fluorescent dye EvaGreen to double stranded DNA. The QuantiTect primer sets for GAPDH (Hs_GAPDH_2_SG QT01192646) and $\beta$-actin (Hs_Actb_2_SGQT01680476) were from Qiagen whereas those for periostin (322445G05 (hPerioS) and 322445G06 (hPerioAS)) were from Invitrogen. The relative quantities of target gene mRNA were compared against two internal controls, GAPDH and $\beta$-actin mRNA, and measured by following a $\triangle \mathrm{CT}$ method employing an amplification plot (fluorescence signal vs. cycle number). The difference $\left(\Delta \mathrm{C}_{\mathrm{T}}\right)$ between the mean values in triplicate samples of the target gene and those of GAPDH and $\beta$-actin mRNAs were calculated by CFX Manager software version 2.1 (Bio-Rad). The relative quantified value (RQV) was expressed as $2^{-\Delta \mathrm{C}_{\mathrm{T}}}$.

\section{Real-time cell invasion assay}

Invasion assays were carried out using the Real-Time Cell Analyser (RTCA) Dual-Plate (DP) Instrument and the xCELLigence system (Roche Diagnostics, QC) following the supplier's instructions. The optimal concentration of TGF- $\beta$ for invasion assay was first determined. U-87 MG cells were transfected with $2 \mathrm{nM}$ siRNAs (Control and periostin) \pm TGF- $\beta$ as described above. After transfection, the upper chamber of a CIM-plate 16 (Roche Diagnostics) was coated with growth factor-reduced Matrigel (BD Biosciences, Bedford, MA) and allowed to polymerize at $37^{\circ} \mathrm{C}$ for $4 \mathrm{~h}$. The lower chamber was filled with serumfree medium and the upper chamber of each well was filled with 20,000 cells. After $30 \mathrm{~min}$ of adhesion, cell invasion was monitored every $15 \mathrm{~min}$ for $24 \mathrm{~h}$ under a humidified atmosphere containing $5 \% \mathrm{CO}_{2}$. The impedance value was measured using the RTCA DP Instrument and expressed as an arbitrary unit called the Cell Index. Each experiment was performed in quadruplicate wells. The results were represented by cell invasion, which represents a ratio of cell index of Matrigel-coated wells to cell index of uncoated wells at a given time point.

\section{Real-time cell migration assay}

Experiments were carried out using the Real-Time Cell Analyser (RTCA) Dual-Plate (DP) Instrument and the xCELLigence system (Roche Diagnostics, QC), following the instructions of the supplier. U-87 MG cells were transfected with $2 \mathrm{nM}$ siRNAs (Control and periostin) \pm TGF- $\beta$ as described above. After transfection, 250000 cells per well were seeded in a CIM-plate 16 (Roche Diagnostics), and incubated at $37^{\circ} \mathrm{C}$ under a humidified atmosphere containing $5 \% \mathrm{CO}_{2}$ for $24 \mathrm{~h}$. Prior to cell seeding, the underside of each well in the upper chamber 
was coated with $0.15 \%$ gelatin in PBS and incubated for 1 $\mathrm{h}$ at $37^{\circ} \mathrm{C}$. The lower chamber was filled with serum-free medium. The upper chamber of each well was filled with 250000 cells. After 30 min of adhesion, cell migration was monitored every $5 \mathrm{~min}$ for $24 \mathrm{~h}$. The impedance value was measured by the RTCA DP Instrument and expressed as an arbitrary unit called the Cell Index. Each experiment was performed in quadruplicate wells.

\section{Statistical analysis}

Statistical analyses were generally performed using one-way ANOVA with a post hoc test Bonferroni's test. Student's unpaired $t$ test was used to determine the statistical significance between the control and the stimulated control for periostin gene expression. Differences with $P<0.05$ were considered significant. All statistical analyses and graphs were performed using the GraphPad Prism software version 5.0b (San Diego, CA).

\section{Abbreviations}

CNS, central nervous system; Cy, cyanidin; Dp, delphinidin; EMT, epithelial mesenchymal transition; GBM, glioblastoma multiforme; Mv, malvidin; Pg, pelargonidin; $\mathrm{Pt}$, petunidin; TGF- $\beta$, transforming growth factor $\beta$.

\section{Author contributions}

Amira Ouanouki performed all the experiments, acquired the data, analyzed, interpreted the results and wrote the manuscript. Sylvie Lamy and Borhane Annabi designed the study, analyzed the data, and wrote the manuscript.

\section{ACKNOWLEDGMENTS AND FUNDING}

This study was funded by the Institutional Research Chair in Cancer Prevention and Treatment held by Dr. Borhane Annabi at UQAM.

\section{CONFLICTS OF INTEREST}

The authors have no conflicts of interest to declare.

\section{REFERENCES}

1. Ratajczak-Wielgomas K, Dziegiel P. The role of periostin in neoplastic processes. Folia Histochem Cytobiol. 2015; 53:120-32. https://doi.org/10.5603/FHC.a2015.0014.

2. Ruan K, Bao S, Ouyang G. The multifaceted role of periostin in tumorigenesis. Cell Mol Life Sci. 2009; 66:2219-30. https://doi.org/10.1007/s00018-009-0013-7.

3. Conway SJ, Izuhara K, Kudo Y, Litvin J, Markwald R, Ouyang G, Arron JR, Holweg CT, Kudo A. The role of periostin in tissue remodeling across health and disease. Cell Mol Life Sci. 2014; 71:1279-88. https://doi. org/10.1007/s00018-013-1494-y.

4. Kudo Y, Siriwardena BS, Hatano H, Ogawa I, Takata T. Periostin: novel diagnostic and therapeutic target for cancer. Histol Histopathol. 2007; 22:1167-74. https://doi. org/10.14670/HH-22.1167.

5. Son H, Moon A. Epithelial-mesenchymal Transition and Cell Invasion. Toxicol Res. 2010; 26:245-52. https://doi. org/10.5487/tr.2010.26.4.245.

6. Jung HY, Fattet L, Yang J. Molecular pathways: linking tumor microenvironment to epithelial-mesenchymal transition in metastasis. Clin Cancer Res. 2015; 21:962-8. https://doi.org/10.1158/1078-0432.ccr-13-3173.

7. Yeung KT, Yang J. Epithelial-mesenchymal transition in tumor metastasis. Mol Oncol. 2017; 11:28-39. https://doi. org/10.1002/1878-0261.12017.

8. Morra L, Moch H. Periostin expression and epithelialmesenchymal transition in cancer: a review and an update. Virchows Arch. 2011; 459:465-75. https://doi.org/10.1007/ s00428-011-1151-5.

9. Mikheev AM, Mikheeva SA, Trister AD, Tokita MJ, Emerson SN, Parada CA, Born DE, Carnemolla B, Frankel S, Kim DH, Oxford RG, Kosai Y, Tozer-Fink KR, et al. Periostin is a novel therapeutic target that predicts and regulates glioma malignancy. Neuro Oncol. 2015; 17:37282. https://doi.org/10.1093/neuonc/nou161.

10. Park SY, Piao Y, Jeong KJ, Dong J, de Groot JF. Periostin (POSTN) Regulates Tumor Resistance to Antiangiogenic Therapy in Glioma Models. Mol Cancer Ther. 2016; 15:2187-97. https://doi.org/10.1158/1535-7163.mct-15-0427.

11. Paolillo M, Serra M, Schinelli S. Integrins in glioblastoma: Still an attractive target? Pharmacol Res. 2016; 113:55-61. https://doi.org/10.1016/j.phrs.2016.08.004.

12. Polivka J Jr, Polivka J, Holubec L, Kubikova T, Priban V, Hes O, Pivovarcikova K, Treskova I. Advances in Experimental Targeted Therapy and Immunotherapy for Patients with Glioblastoma Multiforme. Anticancer Res. 2017; 37:21-33. https://doi.org/10.21873/anticanres.11285.

13. Szopa W, Burley TA, Kramer-Marek G, Kaspera W. Diagnostic and Therapeutic Biomarkers in Glioblastoma: Current Status and Future Perspectives. BioMed Res Int. 2017; 2017:8013575. https://doi.org/10.1155/2017/8013575.

14. Zhang L, Wang X, Lai M. Modulation of epithelial-tomesenchymal cancerous transition by natural products. Fitoterapia. 2015; 106:247-55. https://doi.org/10.1016/j. fitote.2015.09.013.

15. Lin BW, Gong CC, Song HF, Cui YY. Effects of anthocyanins on the prevention and treatment of cancer. $\mathrm{Br}$ J Pharmacol. 2017; 174:1226-43. https://doi.org/10.1111/ bph.13627.

16. Zhang C, Chen W, Zhang X, Huang B, Chen A, He Y, Wang J, Li X. Galunisertib inhibits glioma vasculogenic mimicry formation induced by astrocytes. Sci Rep. 2016; 6:23056. https://doi.org/10.1038/srep23056. 
17. Cao Y, Agarwal R, Dituri F, Lupo L, Trerotoli P, Mancarella S, Winter P, Giannelli G. NGS-based transcriptome profiling reveals biomarkers for companion diagnostics of the TGFbeta receptor blocker galunisertib in HCC. Cell Death Dis. 2017; 8:e2634. https://doi.org/10.1038/cddis.2017.44.

18. Yilmaz M, Christofori G. EMT, the cytoskeleton, and cancer cell invasion. Cancer Metastasis Rev. 2009; 28:1533. https://doi.org/10.1007/s10555-008-9169-0.

19. Acloque H, Adams MS, Fishwick K, Bronner-Fraser M, Nieto MA. Epithelial-mesenchymal transitions: the importance of changing cell state in development and disease. J Clin Invest. 2009; 119:1438-49. https://doi. org/10.1172/jci38019.

20. Ouanouki A, Lamy S, Annabi B. Anthocyanidins inhibit epithelial-mesenchymal transition through a TGFbeta/ Smad2 signaling pathway in glioblastoma cells. Mol Carcinog. 2017; 56:1088-99. https://doi.org/10.1002/ mc. 22575 .

21. Matsuzawa M, Arai C, Nomura Y, Murata T, Yamakoshi Y, Oida S, Hanada N, Nakamura Y. Periostin of human periodontal ligament fibroblasts promotes migration of human mesenchymal stem cell through the alphavbeta3 integrin/FAK/PI3K/Akt pathway. J Periodontal Res. 2015; 50:855-63. https://doi.org/10.1111/jre.12277.

22. Zheng QM, Lu JJ, Zhao J, Wei X, Wang L, Liu PS. Periostin Facilitates the Epithelial-Mesenchymal Transition of Endometrial Epithelial Cells through ILK-Akt Signaling Pathway. Biomed Res Int. 2016; 2016:9842619. https://doi. org/10.1155/2016/9842619.

23. Utispan K, Sonongbua J, Thuwajit P, Chau-In S, Pairojkul C, Wongkham S, Thuwajit C. Periostin activates integrin alpha5beta1 through a PI3K/AKTdependent pathway in invasion of cholangiocarcinoma. Int J Oncol. 2012; 41:1110-8. https://doi.org/10.3892/ijo.2012.1530.

24. Kong DB, Chen F, Sima N. Focal adhesion kinases crucially regulate TGFbeta-induced migration and invasion of bladder cancer cells via Src kinase and E-cadherin. Onco Targets Ther. 2017; 10:1783-92. https://doi.org/10.2147/ott. s122463.

25. Reif S, Lang A, Lindquist JN, Yata Y, Gabele E, Scanga A, Brenner DA, Rippe RA. The role of focal adhesion kinasephosphatidylinositol 3-kinase-akt signaling in hepatic stellate cell proliferation and type I collagen expression. J Biol Chem. 2003; 278:8083-90. https://doi.org/10.1074/jbc. M212927200.

26. Kwiatkowska A, Kijewska M, Lipko M, Hibner U, Kaminska B. Downregulation of Akt and FAK phosphorylation reduces invasion of glioblastoma cells by impairment of MT1MMP shuttling to lamellipodia and downregulates MMPs expression. Biochim Biophys Acta. 2011; 1813:655-67. https://doi.org/10.1016/j.bbamcr.2011.01.020.

27. Han J, Alvarez-Breckenridge CA, Wang QE, Yu J. TGFbeta signaling and its targeting for glioma treatment. Am J Cancer Res. 2015; 5:945-55. https://doi.org/10.3390/ jem5110096.
28. Herbertz S, Sawyer JS, Stauber AJ, Gueorguieva I, Driscoll KE, Estrem ST, Cleverly AL, Desaiah D, Guba SC, Benhadji KA, Slapak CA, Lahn MM. Clinical development of galunisertib (LY2157299 monohydrate), a small molecule inhibitor of transforming growth factor-beta signaling pathway. Drug Des Devel Ther. 2015; 9:4479-99. https://doi.org/10.2147/dddt.s86621.

29. Hu Q, Tong S, Zhao X, Ding W, Gou Y, Xu K, Sun C, Xia G. Periostin Mediates TGF-beta-Induced Epithelial Mesenchymal Transition in Prostate Cancer Cells. Cell Physiol Biochem. 2015; 36:799-809. https://doi. org/10.1159/000430139.

30. Chen M, Zheng SH, Liu Y, Shi J, Qi ST. Periostin activates pathways involved in epithelial-mesenchymal transition in adamantinomatous craniopharyngioma. J Neurol Sci. 2016; 360:49-54. https://doi.org/10.1016/j.jns.2015.11.042.

31. Kanno A, Satoh K, Masamune A, Hirota M, Kimura K, Umino J, Hamada S, Satoh A, Egawa S, Motoi F, Unno M, Shimosegawa T. Periostin, secreted from stromal cells, has biphasic effect on cell migration and correlates with the epithelial to mesenchymal transition of human pancreatic cancer cells. Int J Cancer. 2008; 122:2707-18. https://doi. org/10.1002/ijc.23332.

32. Kim CJ, Sakamoto K, Tambe Y, Inoue H. Opposite regulation of epithelial-to-mesenchymal transition and cell invasiveness by periostin between prostate and bladder cancer cells. Int J Oncol. 2011; 38:1759-66. https://doi. org/10.3892/ijo.2011.997.

33. Wu SQ, Lv YE, Lin BH, Luo LM, Lv SL, Bi AH, Jia YS. Silencing of periostin inhibits nicotine-mediated tumor cell growth and epithelial-mesenchymal transition in lung cancer cells. Mol Med Rep. 2013; 7:875-80. https://doi. org/10.3892/mmr.2013.1267.

34. Yan W, Shao R. Transduction of a mesenchyme-specific gene periostin into $293 \mathrm{~T}$ cells induces cell invasive activity through epithelial-mesenchymal transformation. J Biol Chem. 2006; 281:19700-8. https://doi.org/10.1074/jbc.M601856200.

35. Di Daniele N, Noce A, Vidiri MF, Moriconi E, Marrone G, Annicchiarico-Petruzzelli M, D’Urso G, Tesauro M, Rovella V, De Lorenzo A. Impact of Mediterranean diet on metabolic syndrome, cancer and longevity. Oncotarget. 2017; 8:894779. https://doi.org/10.18632/oncotarget.13553.

36. Kwan HY, Chao X, Su T, Fu X, Tse AK, Fong WF, Yu ZL. The anticancer and antiobesity effects of Mediterranean diet. Crit Rev Food Sci Nutr. 2017; 57:82-94. https://doi.or g/10.1080/10408398.2013.852510.

37. Wang S, Shen P, Zhou J, Lu Y. Diet phytochemicals and cutaneous carcinoma chemoprevention: A review. Pharmacol Res. 2017; 119:327-46. https://doi. org/10.1016/j.phrs.2017.02.021.

38. Cerletti C, De Curtis A, Bracone F, Digesu C, Morganti AG, Iacoviello L, de Gaetano G, Donati MB. Dietary anthocyanins and health: data from FLORA and ATHENA EU projects. Br J Clin Pharmacol. 2017; 83:103-6. https:// doi.org/10.1111/bcp.12943. 
39. Wu X, Pittman HE 3rd, Prior RL. Pelargonidin is absorbed and metabolized differently than cyanidin after marionberry consumption in pigs. J Nutr. 2004; 134:2603-10. https://doi. org/10.1093/jn/134.10.2603.

40. Marczylo TH, Cooke D, Brown K, Steward WP, Gescher AJ. Pharmacokinetics and metabolism of the putative cancer chemopreventive agent cyanidin-3-glucoside in mice. Cancer Chemother Pharmacol. 2009; 64:1261-8. https://doi.org/10.1007/s00280-009-0996-7.

41. Passamonti S, Vrhovsek U, Vanzo A, Mattivi F. Fast access of some grape pigments to the brain. J Agric Food Chem. 2005; 53:7029-34. https://doi.org/10.1021/jf050565k.

42. Friedl P, Wolf K. Tumour-cell invasion and migration: diversity and escape mechanisms. Nat Rev Cancer. 2003; 3:362-74. https://doi.org/10.1038/nrc1075.

43. Yamaguchi H, Condeelis J. Regulation of the actin cytoskeleton in cancer cell migration and invasion. Biochim Biophys Acta. 2007; 1773:642-52. https://doi. org/10.1016/j.bbamcr.2006.07.001.

44. Roth P, Silginer M, Goodman SL, Hasenbach K, Thies S, Maurer G, Schraml P, Tabatabai G, Moch H, Tritschler I, Weller M. Integrin control of the transforming growth factor-beta pathway in glioblastoma. Brain. 2013; 136:564 76. https://doi.org/10.1093/brain/aws351.

45. Yang Y, Shi Z, Reheman A, Jin JW, Li C, Wang Y, Andrews MC, Chen P, Zhu G, Ling W, Ni H. Plant food delphinidin3-glucoside significantly inhibits platelet activation and thrombosis: novel protective roles against cardiovascular diseases. PLoS One. 2012; 7:e37323. https://doi. org/10.1371/journal.pone.0037323.

46. Kang MK, Lim SS, Lee JY, Yeo KM, Kang YH. Anthocyanin-rich purple corn extract inhibit diabetesassociated glomerular angiogenesis. PLoS One. 2013; 8:e79823. https://doi.org/10.1371/journal.pone.0079823.

47. Kumar R, Deep G, Wempe MF, Agarwal R, Agarwal C. Procyanidin B2 3,3"-di-O-gallate inhibits endothelial cells growth and motility by targeting VEGFR2 and integrin signaling pathways. Curr Cancer Drug Targets. 2015; 15:14-26. https://doi.org/10.2174/1568009614666141229 102254.

48. Seeram NP, Nair MG. Inhibition of lipid peroxidation and structure-activity-related studies of the dietary constituents anthocyanins, anthocyanidins, and catechins. J Agric Food Chem. 2002; 50:5308-12. https://doi.org/10.1021/ jf025671q.

49. Katz LH, Li Y, Chen JS, Munoz NM, Majumdar A, Chen J, Mishra L. Targeting TGF-beta signaling in cancer. Expert Opin Ther Targets. 2013; 17:743-60. https://doi.org/10.151 7/14728222.2013.782287.

50. de Gramont A, Faivre S, Raymond E. Novel TGF-beta inhibitors ready for prime time in onco-immunology. OncoImmunology. 2016; 6:e1257453. https://doi.org/10.1 080/2162402X.2016.1257453.

51. Serova M, Tijeras-Raballand A, Dos Santos C, Albuquerque M, Paradis V, Neuzillet C, Benhadji KA, Raymond E, Faivre S, de Gramont A. Effects of TGF-beta signalling inhibition with galunisertib (LY2157299) in hepatocellular carcinoma models and in ex vivo whole tumor tissue samples from patients. Oncotarget. 2015; 6:21614-27. https://doi.org/10.18632/oncotarget.4308.

52. Dituri F, Mazzocca A, Fernando J, Papappicco P, Fabregat I, De Santis F, Paradiso A, Sabba C, Giannelli G. Differential Inhibition of the TGF-beta Signaling Pathway in HCC Cells Using the Small Molecule Inhibitor LY2157299 and the D10 Monoclonal Antibody against TGF-beta Receptor Type II. PLoS One. 2013; 8:e67109. https://doi.org/10.1371/ journal.pone.0067109.

53. Dwivedi SK, McMeekin SD, Slaughter K, Bhattacharya R. Role of TGF-beta signaling in uterine carcinosarcoma. Oncotarget. 2015; 6:14646-55. https://doi.org/10.18632/ oncotarget. 3711.

54. Zhang J, Deng YT, Liu J, Wang YQ, Yi TW, Huang BY, He SS, Zheng B, Jiang Y. Norepinephrine induced epithelialmesenchymal transition in HT-29 and A549 cells in vitro. J Cancer Res Clin Oncol. 2016; 142:423-35. https://doi. org/10.1007/s00432-015-2044-9.

55. Afrin S, Giampieri F, Gasparrini M, Forbes-Hernandez TY, Varela-Lopez A, Quiles JL, Mezzetti B, Battino M. Chemopreventive and Therapeutic Effects of Edible Berries: A Focus on Colon Cancer Prevention and Treatment. Molecules. 2016; 21:169. https://doi.org/10.3390/ molecules21020169. 